\title{
Política Transnacional N egra, Antiimperialismo e Etnocentrismo para Pierre Bourdieu e Loïc Wacquant: Exemplos de Interpretação Equivocada*
}

M ichael $\mathrm{H}$ anchard

Resumo

Com o objetivo de ampliar a discussão em torno do discurso de Bourdieu eW acquant, o objetivo desteartigo éfazer uma interven ção específica em resposta ao artigo deles no que diz respeito ao $M$ ovimento N egro no Brasil, o movimento por direitos civis nos Estados U nidose políticas negras transnacionais. 0 principal argumento do autor équea crítica dos dois autores baseia-se em suposições e métodos analíticos críticos que privilegiam o Estado nacional ea cultura "nacional" como objetos únicos da análise comparativa ignorando como a política afro-brasileira, osmovimentos por direitoscivisnosEU A, em particular, e a política negra transnacional, de maneira mais geral, problematizam as distinções fáceis, até mesmo os superficiais, entre Estados-nações e populações imperialistas e antiimperialistas dessa crítica. Ambos, o M ovimento $\mathrm{N}$ egro brasileiro eo movimento por direitos civisnos EU A, são analisad os unicamente como fenômenos de territórios nacionais, inteiramente auto-referentes (ou seja, provincianos), sem ligações entre si. T aislimitações de interpretação brotam da incapacidadedeidentificar e reconhecer formas de cultura e política não necessariamente coinciden-

* Versão revisada para T heory, Cultureand Society, 7 dejaneiro de 2002. Tradução deAngela M elim.

Estudos Afro-Asiáticos, Ano 24, no 1, 2002, pp. 63-96 
tes com política partidária, nacionalista (identidade) e sindicalista classista, formas de política das quais, na maior parte do século XX, as populações negras dos Estados U nidos, Brasil e até mesmo França, ficaram, em larga medida, excluídas e até mesmo marginalizadas.

Palavras-chave: relações raciais, movimento negro no Brasil, movimento negro americano, Bourdieu, Wacquant.Abstract

\section{Abstract}

Acts of M isrecognition: Transnational Black Politics, Anti-imperialism, and the Ethnocentrisms of Pierre Bourdieu and Loïc Wacquant

This paper aims at enlarging the discussion about Bourdieu and Wacquant ideas doing a particular intervention for answering their article in relation to the Black M ovement in Brazil, the movement for civil rights in the US and the transnational black politics. The author's main reason is that Bourdieu and W acquant's criticisms have been based on suppositions and critical analytical methods that emphasize the $\mathrm{N}$ ational State and the "national" culture. They also misinterpret the perception among nation-States, imperialistic and anti-imperialistic populations in their review. Both, the Brazilian Black M ovement and the movement for civil rights in the US, are analysed as a national territory phenomenon, without connections between themselves, seen as completely "provincial". These limitations of interpretation have started from the incapacity of identifying and recognizing forms of culture and policy not necessarily coincident with party policies, national identity policy and labour unions. In addition to this fact, in the majority of the XX century, black population in the US, Brazil and even in France, remained, in a high degree, excluded and marginalized from forms of policy.

Keywords: racial relations, Black M ovement in Brazil, movement for civil rights, Bourdieu, Wacquant. 
Política T ransnacional N egra, Antiimperialismo eEtnocentrismo...

Résumé

Politique $\mathrm{N}$ oire Transnationale, Anti-impérialisme et

Ethnocentrisme sel on Pierre Bourdieu et Loïc Wacquant: Exemples d'une Interprétation Erronée

Souhaitant élargir l'analyse à propos du discours de Bourdieu et Wacquant, on cherche ici à répondre à leur article concernant le mouvement des $\mathrm{N}$ oirs au Brésil, le mouvement pour les droits civils aux États-U nis et les politiques transnationales concernant les $\mathrm{N}$ oirs. Comme principal argument, on pose que la critique proposée par ces deux auteurs se fonde sur des suppositions et des méthodes analytiques qui privilégient l'État national et la culture "nationale", comme seuls objets de leur analyse comparative: ils laissent de côté la façon dont la politique afro-brésilienne, les mouvements pour les droits civils aux États-U nis, en particulier, et la politique transnationale concernant les $\mathrm{N}$ oirs, de façon plus générale, empêchent les distinctions hâtives, voire superficielles, entre États-nations et populations impérialistes et anti-impérial istes. Tous deux, le mouvement des $\mathrm{N}$ oirs brésiliens ainsi que le mouvement pour les droits civils aux États-U nis, sont examinés uniquement comme des phénomènes de territoires nationaux, référés exclusivement à eux-mêmes - c'est à dire, trop restreints - sans rapport entre eux. Ces interprétations limitées naissent de leur incapacité à identifier et reconnaître des formes culturelles et politiques ne coïncidant pas nécessai rement avec une politique de partis, nationaliste (identité) et syndicaliste catégoriel, des modèles politiques dont ont été exclues ou mises en marge, pendant presque tout le $X X^{e}$ siècle, les populations noires des États-U nis, du Brésil et même de la France.

$M$ ots-clé: relations raciales, mouvement des $\mathrm{N}$ oirs au Brésil, mouvement des $\mathrm{N}$ oirs nord-américains, Bourdieu, Wacquant 
IT he Cunning of Cultural Imperialism" - ensaio de Pierre Bourdieu eL oïc W acquant, publicado em Theory, Culture and Society, fez com que eu me identificasse, entre diversos outros acadêmicos norte-americanos, com a reprodução e disseminação do imperialismo cultural dosEU A, através de trabalho acadêmico quetenta fazer as relações raciais no B rasil se parecerem com o modelo supostamente bipolar dos Estados U nidos. Ao proceder assim, segundo a crítica deles, engajei-me em uma forma de chauvinismo nacionalista, que descrevem como "veneno etnocêntrico" (Bourdieu \& W acquant, 1999).

U $m$ de seus alvos foi meu livro 0 rfeu e o Poder, com a acusação de que viajei para o Brasil e usei - em relação à questão da raça - uma lentenormativa moldada nos Estados U nidos, com isso exibindo duas formas de comportamento notadamente imperial ista: a) avaliei o Brasil eo movimento negro brasileiro deacordo com os contornos das relações raciais nos Estados U nidos; eb) fiz proselitismo em meio ao movimento negro brasileiro, na tentativa de convencêlo dequetal movimento deveria se parecer com o "movimento por direitos civis dosEU A" em estratégia, táticaeatéclassificação racial. Esse suposto crime é descrito em termos abstratos, na frase de abertura, por "seu poder de universalizar particularismos ligados a uma tradição histórica singular, fazen do com quesejam reconhecidos como tais". O s "particularismos", nesse caso, são estratégias etáticas que evoluíram da "tradição histórica singular" do movimento pelos direitos civis dos EUA.

Como observaram diversas pessoas, em resposta à edição especial anterior, dedicada a esse debate, Bourdieu eW acquant estão profundamente implicados com a própria crítica, ignorando heranças do imperialismo francês, colonialismo, bem como o conhecimento das intrincadas rel ações raciais no B rasil. Asvárias reações aos seus discursos sugerem que as implicações desse debate ressoam nos quatro cantos do mundo, inclusive em setores acadêmicos muito distantes dos estudos brasileiros ou latino-americanos. A fim de ampliar a discussão em torno da arenga de Bourdieu eW ac- 
quant, eu gostaria de fazer uma intervenção muito específica em resposta ao artigo deles - a qual não foi elaborada anteriormenterelativa ao $\mathrm{M}$ ovimento $\mathrm{N}$ egro no Brasil, o movimento por direitos civis nos Estados U nidos e políticas negras transnacionais. A crítica del es baseia-se em suposi ções e métodos analíticos críticos que privilegiam o Estado nacional ea cultura "nacional" como objetos únicos da análise comparativa e, conseqüentemente, ignora como a política afro-brasileira, os movimentos por direitos civis nos EU A, em particular, e a política negra transnacional, de maneira mais geral, problematizam as distinções fáceis, até mesmo superficiais, entre Estados-nações e populações imperialistas e antiimperialistas dessa crítica. Ambos, o M ovimento $\mathrm{N}$ egro brasileiro e 0 movimento por direitos civisnosEU A, são analisados unicamente como fenômenos deterritórios nacionais, inteiramente auto-referentes (ou seja, provincianos), sem ligações entre si.

Esta constelação particular de suposições e métodos expõe uma combinação latinista de Estado e nação, dentro da qual o popular nacional eo aparato do Estado não se distinguem um do outro. Em sua visão, as populações nacionais são alinhadas por fixidez territorial, cultural eno Estado. Assim, os cidadãos brasileiros e norte-americanos em geral, e os afro-brasileiros e afro-norteamericanos dos EU A em particular, são divididos de acordo com as coordenadas acima mencionadas. É impossível, dentro desse molde, identificar e ler diferenças culturais e ideológicas no interior dos Estados U nidos ou do Brasil. Também não existe a possibilidade de divisões, interesses coincidentes, pontos em comum, ideológicos ou culturais, que possam atravessar fronteiras de nação, "cultura nacional e E stado". Além disso, não se cogita a perspectiva de distinção interna, a idéia de que o povo deum país possa compartilhar afinidades e políticas que, defato, vão contra o Estado, ou mesmo ideologias populares dominantes a respeito de uma nação ou povo em particular. I sto não só constituiria uma surpresa para indivíduos, organizações e movimentos dentro dos Estados U nidos, que há muito tempo resistem a políticas - domésticas e de fora - de imperial ismo eaparthei d social em casa e no estrangeiro, mas também um insulto. E o principal, em se tratando de avaliar academicamente a crítica deles, é que Bourdieu eW acquant ignoram a complexidade ou especificidade da atuação negra, tanto no Brasil quanto nos Estados U nidos, o que os leva a equacionar transnacionalismo negro com imperialismo e política externa dos EU A. Em sua versão do etnocentrismo político, são privilegiadas as políticas dos Estados-nações, enquanto mobilizações de atores 
Política T ransnacional N egra, Antiimperialismo eEtnocentrismo...

não estatais são negligenciadas e, quando identificadas, precariamente compreendidas.

\section{A Tese da Incorrigibilidade versus Política sem D elimitação}

0 argumento de Bourdieu e W acquant retoma, sob certos aspectos, o que C harles Taylor chamou de "tese da incorrigibilidade", em que a cultura serve como linguagem, símbolo e prática de uma comunidade del imitada, demarcada. Essa forma de comunidade acaba gerando um fosso, quando justaposta a outras comunidades da mesma espécie. C ria-se não só uma situação do tipo Babel, de impossibilidade de compreensão mútua, mastambém possibilidade de interpretação equivocada, com base na presunção de superioridade cultural. As tentativas de intercâmbio de uma cultura dominante com uma outra, subordinada, são particularmente afetadas pelo perigo de violência na interpretação quando os intérpretes de uma cultura dominante assumem que seu papel é

[...] corrigir a autocompreensão dos que dominam menos, substituindo-a pela sua própria. 0 queocorre, de fato, nessecaso ésimplesmenteo seguinte: nós somos capazes de reconhecer em nossos própriostermos; e as autodescrições deles estão erradas na medida em que se desviam das nossas. 0 s estudos tran sculturais tornam-se campo de exercício de preconceito etnocêntrico. (T aylor, 1985:124, ênfase no original)

No âmbito do método, Taylor tenta fazer a ponte entre 0 "nós" e o "eles" através de um processo de compreensão crítica, mutuamente engajada, segundo o qual não se pode empreender a interpretação de uma outra cultura "enquanto também não tivermos nos compreendido melhor" (idem:129). Taylor, éclaro, utiliza a sua própria abordagem interpretativa como antídoto para a noção de que a diferença cultural exclui a possibilidade de qualquer pessoa empreen der uma análise de uma outra sociedade, civilização e cultura sem ficar tão cega pelo próprio chauvinismo de modo que suas observações se tornem, logo de cara, suspeitas. Há mais detrinta anos atrás, quando esteartigo foi publicado pela primeira vez, diversas noções antropológicas, bem como noções mais ligadas ao senso comum, de diferença cultural, supunham que as culturas constituíssem processos discretos, separados. 0 argumento de Bourdieu eW acquant contém traços da tese da incorrigibilidade, na medida em que nacionalidade ou "nacionação" serve como forma de distinção cultural (história, política e cultura da nação) que radical mente diferencia uma formação nacional de ou- 
tra, neste caso, o Brasil eos brasilei ros, dosEU A eosamericanos. A versão deles é complementada por um cenário-caso "empírico": 0 Estado americano, seus cidadãos, escravos, indígenas e outros povos dominados, bem como os capitalistas com basenos EU A, que evoluíram e se tornaram corporaç̃os multinacionais. Todos estes acima não são apenas indistinguíveis, mas intercambiáveis.

A tese da incorrigibilidade de Taylor ea crítica deBourdieu e W acquant compartil ham uma forma comum de lógica. Ambas as formulações pressupõem formações culturais estáveis e internamente coerentes, na medida em que a diferença cultural se baseia em uma oposição binária "nós" versus "eles". Em termosanalíticos, a diferença cultural também coincide com a distinção espacial, de tal modo quea idéia de diferença cultural édelimitada por diferença territorial, que é, por sua vez, presidida por um Estado, cujas políticas (imperialistas, antiimperialistas etc.) determinam a disposição ideológica nacional do(s) povo(s) ao(s) qual (is) assegura cidadania ou dominação. Aqui, a distinção crucial équeTaylor coloca sua tese com o fim de transcendế-la, enquanto Bourdieu e W acquant assumem como verdadei ros os preceitos epistemológicos da tese. Assim, os Estados U nidos constituem uma homologia; seus intelectuais, seus ativistas e sua gente comum têm necessariamente de refletir as ideologias dominantes, imperialistas, do Estado, da sociedade nacional eda cultura dos EU A. Sua "nacionação" supera quaisquer posições e distinções culturais, políticas ou ideológicas que possam vir a possuir e articular.

2. O M ovimento por Direitos Civis: Esse $\mathrm{O}$ bscuro $\mathrm{O}$ bjeto do Imperialismo dos EUA?

0 movimento por direitos civis dos EU A servecomo importante símbolo e dispositivo retórico no argumento de Bourdieu e W acquant, no sentido de identificar um sintoma do imperial ismo dos EUA, um exemplo paradigmático de um tipo particular de protesto político esocial aparentemente peculiar dos EstadosU nidos, uma espécie de marcador, indicador estável, confiável, "dado" de uma formação ideológica singular. D epois de me acusar de "aplicar categorias raciais norte-americanas à situação brasileira" e tentar transformar a "história particular do movimento por direitos humanos nos EU A em padrão universal para a luta de todos os grupos oprimidos com base em cor (ou casta)" (Bourdieu \& W acquant, 1999:44), eles colocam a seguinte questão retórica: 
Política T ransnacional N egra, Antiimperialismo eEtnocentrismo...

[...] na verdade, o que pensar de pesquisadores norte-americanos que viajam ao Brasil para estimular líderes do M ovimento N egro a adotar táticas do movimento afro-norte-americano por direitos civis edenunciar a categoria de pardo [...] com o fim de mobilizar todos os brasileiros de descendência africana em torno da oposição dicotômica entre "afro-brasileiros" e "brancos" no mesmo momento em que, nos Estados U nidos, gente de origem mista, inclusive os chamados negros, estão se mobilizando para obter do Estado norte-americano (a começar pelo órgão do ( enso), o reconhecimento oficial dos americanos "mestiços", deixando de os classificar à força como "negros".

Embora seja, sem dúvida, plausível e, em alguns casos, verdadeiro que certos defensores do movimento por direitos civis dos EUA, particularmentenos fórunsinternacionais, coloquem o ativismo por direitos civis nos Estados U nidos como model o para 0 ativismo negro em outras partes do mundo, podendo-se, portanto, considerar hegemônicas suas aspirações, seria, porém, o caso de sejulgar, demodo muito específico, a particularidade da intervenção, em vez de simplesmente atribuir tais aspirações a uma forma de política de identidade (nação, raça) de todo um agrupamento ou congregação política.

0 uso quefazem da expressão "movimento por direitos civis dosEU A" e "afro-norte-americano" fornece outrachave para a nuvem de hipóteses sem fundamento que paira em torno do argumento deles. Embora o fato de ser "norte-americano" ou, mais especificamente, "afro-norte-americano" pudesse servir para selocalizar uma categoria em particular de cidadão/súdito dos EU A, isto não chega a significar sequer um passo inicial para se identificar, localizar e, em última instância, discernir, uma posição política. Em outras palavras, apesar de 0 racismo em uma sociedade tal como a dosE stados U nidos criar condições materiaispara quepossam emergir e, de fato, emerjam certos modos de consciência, ele não dita, em última análise, estados de consciência ou como indivíduos e grupos reagem a essas condições. Assim, aquilo que para esses críticos servecomo variável explicativa é, na verdade, umacategorização totalizante, que requer, el a própria, explicação equalificação.

N o caso deafro-norte-americanos dosEU A (leitores, por favor, notem a distinção), a análise "afro-norte-americana" seria integracionista ou nacionalista negra, marxista, liberal ou conservadora - só para mencionar diversas de muitas possibilidadesideológicas? Essetipo de especificidade seria derigueur para a crítica séria nas $\mathrm{C}$ iências Sociais e H umanidades, o primeiro "corte" de qual- 
quer investigação revisionista, historiográfica, sociológica, que tentassesituar um modo particular de análise dentro de uma tradição intelectual específica. E, no entanto, tal requisito, prima facie, parece estar suspenso das críticas de Bourdieu e W acquant. Seria possível levar a sério uma pessoa que anal i sasse a $\mathrm{F}$ rança modernae argumentasseque o queBataille, o conde G obineau, J ulia K risteva e H enri LeF ebvre fazem - citando apenas quatro pensadores - é al go que remotamente lembre um modo "francês" de análise? A sutil e detal hada resposta de R obert Stam eEllaShohat a Bourdieu eW acquant enfatiza e põe a sal vo o lado francófilo do debatefranco-americano, de modo que não estenderia meu argumento nessa direção (Shohat e Stam, 2001). Levanto essas questões porque provêem lente mais ampla para minha resposta às afirmações de Bourdieu e W acquant a respeito do imperialismo supostamente inerentena transmissão e emprego de modos de prática política do movimento por direitos civis dos EU A utilizados com bom resultado em outros lugares.

$N$ estecaso, as afirmativas dos dois críticos trazem falta de familiaridade com o meu trabalho - pré requisito para se fazer crítica desse tipo. Tenho consistentemente sublinhado a equação problemática da América com os Estados U nidos e argumentado, como Richard M oore, o radical afro-caribenho dos anos 1930, 1940 (M oore, 1992), ou, mais contemporâneos, C aetano Vel oso e Pablo M ilanés, queo conceito de América, eaté mesmo o de Amé rica do $\mathrm{N}$ orte, abrange muito mais que os Estados U nidos. Em um ensaio escrito há mais de dez anosargumentei a favor do uso da expressão afro-norte-americano e norte-americano como designação hemisférica, em vez de nacional, e tenho, de maneira consistente, utilizado a expressão afro-norte-americano nas minhas referências à maior parte (embora não todos) dos povos de descendência africana nos Estados U nidos ( $\mathrm{H}$ anchard, 1990). Assim, o primeiro exemplo de interpretação equivocada da parte desses críticos, à primeira vista menor, não deixa, porém, de sugerir formas mais visíveis de má intepretação, que se seguirão.

Em prol da argumentação, quero tornar clara a condicional embutida na questão retórica del es, reproduzida no início destaseção: e se al guém dos Estados U nidos, familiarizado com a luta negra pela igualdade racial, saísse dos Estados U nidos e sugerisse a membrose ativistas de um outro grupo subordinado em função da raça que as táticas praticadas nos EU A podem ter alguma viabilidade política em outros lugares? M as a questão que está, de fato, em pauta éselivreassociação, identidade cultural, reunião política 
e protesto constituem assuntos tão específicos, em termos culturais, a ponto de serem incorrigíveis e, conseqüentemente, imutáveis. I números exemplos sugerem quenão éesta, necessariamente, a consequêencia do deslocamento de estratégias, táticas efilosofias da práxis. As táticas de $\mathrm{G}$ handi de desobediência civil, informadas em parte pelos escritos de $H$ enry D avid Thoreau, não 0 transformam em um "norte-americano", nem transformam a Índia, da luta nacionalista, em Estados U nidos. T ampouco a resistência anti-racista de G handi aos bôers, na África do Sul, converte a Índia na U nião da África do Sul.

As idéi as, táticas e estratégias da maior parte dos movimentos pelos direitos civis enacionalistas negros não emanam do Estado nem do capital, mas da interação da luta popular com as filosofias da práxis que tiveram dimensões locais, nacionais e transnacionais. Talvez me fal he a memória, mas não me lembro da M onsanto ou D ow Chemical, de Richard N ixon, Lyndon Johnson ou quaisquer outros atores político-econômicos da era do movimento moderno por direitos civis a advogar disseminação global de idéias etáticas de atores políticos negros dos Estados U nidos. U tilizando a velha distinção de Miliband (1983), com exceção de umas poucas organizações e indivíduos ligados ao $\mathrm{FBI}$ eà $\mathrm{CI} \mathrm{A}$, os movimentos sociais negros da era dos direitos civis não trabal haram, nem a mando, nem a favor do capital ou do Estado. Se determinados comentaristas e estudantes da época buscaram, nos sentidos literal e figurado, universalizar suas estratégias, crenças e táticas no diálogo com movimentos em outras partes - é outra questão. M as eu aqui gostaria de levar minha resposta mais um passo adiante; a circulação deidéias, táticas efilosofias das lutas por direitos civis negros nos Estados U nidos ou em qualquer outro lugar é útil para a circulação contínua da discussão sobre a rel ação entre poder e cultura na esfera pública transnacional negra. É um passo em direção à transcendência (se éque é possível) das limitações de ambos os argumentos: de um lado, os direitistas, sobrea inferioridade cultural ou biológica de uma espécie de sujeitos, africanos e descendentes de africanos; de outro, os esquerdistas (europeus e outros), que relegam a política transnacional negra ao reino do sempre exótico, ou pior, "provinciano".

As suposições de Bourdieu eW acquant a respeito do "movimento por direitos civis dos EUA" tornam-se ainda mais sem sentido quando se considera o caráter global izado da luta negra nos Estados U nidos, não só durante a era do movimento dos direitos civis, mas ao longo de pelo menos dois séculos. A armadilha que 
armaram para si mesmos com a categoria analítica de nação territorial os leva a aprisionar a política e o pensamento afro-norteamericanos dos EU A dentro das fronteiras geográficas dos EU A. Suas afirmações, porém, provêem a oportunidade de se considerar o assim chamado movimento por direitos civis dosEU A dentro do contexto mais amplo da luta por igualdade racial, ação e consciência coletiva entre afro-norte-americanos dos EU A face à supremacia, indiferença e condescendência brancas e como esse contexto seencaixa na pai sagem ainda mais ampla do transnacionalismo negro, de que fazem parte tanto atores políticos afro-brasileiros como afro-norte-americanos dos EU A.

U m dos pilaresfil osóficos da mais conhecida tradição deativismo político negro, a saber, a desobediência civil da Southern Christian Leadership Conference - SN CC e do Student N on$V$ iolent C oordinating C ommittee - SCLC foi a filosofia da desobediência civil deM ohandasG handi, elepróprio influenciado por $\mathrm{H}$ enry Thoreau e R alph Wal do Emerson. I déias "estrangeiras" das obras de Frantz Fanon, Albert $\mathrm{M}$ emmi, $\mathrm{H}$ o Chi M inh e Amilcar Cabral (incluindo até mesmo autores franceses, como Sartree Régis D ebray), penetraram nos debates no interior de movimentose associações como Panteras N egras, Exército Simbionês de Libertação, $O$ ficina de E scritores Watts (W atts W riters W orkshop), 0 ficina de $\mathrm{E}$ scritores do $\mathrm{H}$ arlem (H arlem W riters W orkshop) e outros grupos, durante os anos 1960, e integraram o desenvolvimento ideológi co etático daluta pela libertação dosnegros. Q uando se leva em conta que afro-norte-americanos que não são dos EU A freqüentemente ocuparam posi ções intelectuais e estratégi cas significativas em várias ten dên cias no interior da luta negra por igualdade racial nos EU A - de gente como K wame Toure (née Stokely Carmichael) a C yril Biggs e Claudia ones - , então, o "movimento afro-norte-americano", ou seja, o citado "movimento por direitos civis dosEU A", foi plural, tanto em termosideológicos quanto etno-nacionais.

Como a maioria dos estudiosos do período pós-Segunda G uerra nos Estados U nidos sabe, a época conteve, porém, muitas tendênciasideológi cas e de mobilização, al gumasnão diretamente ligadas ao movimento por direitos civis: nacionalismos negros de vários tipos, a nação do islã, estratégias revolucionárias utilizando luta armada, entre outras. $M$ al se pode pensar em reagir à idéia de um movimento por direitoscivis dosEU A (capitalizar?) como sendo uma entidade monolítica com, na melhor das hipóteses, dois núcleosprincipais, o SN CC eo SC LC , ou talvez três, incluindo-se 
as causas e ideologias do Black Power, a não ser que, maisuma vez, se vá repreender esses críticos por sua fal ta cabal de familiaridade com os contornos mais smplos dalutanegra nos Estados U nidos.

Isto deveria estar óbvio para quem tem familiaridade, mesmo ligeira, com a história dos EU A. M enos óbvio écomo dois estudiosos como Bourdieu e W acquant, que se criaram no interior de e em relação com um ex-poder imperial como a F rança, conseguiram escapar do vício das mitologias nacionais francesas elógicas culturais corporativistas. Se o discurso de Bourdieu tem como origem o Sudoeste da França, el e deveria sentar-se, com um copo deJ urancon ou $\mathrm{M}$ adiran (para manter a integridade regional), elevar em consideração a obra de Robin D. G . K elley (1999), K elley e T iffany Patterson (2000), Penny von Eschen (1997), W inston James (1998), M ark N aison (1984), C edric Robinson (1983) e M ichael D awson (2001), entre outros, para compreender o que muitos nosEU A e outros lugaresjá entenderam há muito tempo: 0 assim chamado movimento por direitos civis dos EU A não ficou limitado aos Estados U nidos, e a luta "negra" não foi inteiramente negra. Isto contraria diretamente a sugestão de Bourdieu e W acquant dequeatransmissão de idéias sobreluta social entreos EstadosU nidose o resto do mundo tem sido "unidirecional" ou unilinear. A suposição de Bourdieu eW acquant de que a simples perspectiva de tática móvel é uma estratégia que emana dos Estados U nidos, não passando de "veneno etnocêntrico", exemplifica sua falta de imaginação política.

A segunda parte da colocação sobre a astúcia do imperialismo dosEU A refere-seao papel dasinstituições decusteio, publicação e pesquisa que operam como cadeia de tran smissão para que 0 "doxa racial" dos EU A seja empurrado Brasil abaixo. A ortodoxia queimputam aos EU $A$ quanto ao princípio que regea distribuição da verbanão tem o apoio da evidência de um lequediversificado de suporte a miríades de iniciativas para incrementar não só o trabaIho acadêmico, mas a presença de brasileiros negros e mulatos nos programas de pesquisa de pós-graduação em Ciências Sociais e H umanidades, bem como a proliferação de Organizações $\mathrm{N}$ ão-G overnamentais e atores que defendem causas relativas aos direitos humanos e têm preocupações que afetam os negros e mulatos brasileiros.

A versão de Bourdieu eW acquant da tese da incorrigibilidadeexclui a possibilidadedeinstituições de financiamento sediadas nos EU A de fato se colocarem na posição de promover, mais que perverter, o ativismo nacional e/ou local, mas, mais uma vez, as 
implicações internacionais e transnacionais da política racial no B rasil - assim como o financiamento não- governamental em todo o mundo - são bem mais complexas do querevelam seusargumentos. Para dar alguns exemplos concretos, a Fundação F ord tem financiado diversos programas de pós-graduação em várias universidades, em várias partes do país, a fim de aumentar a presença de brasi lei ros negros e mulatos na academia brasileira que, historicamente, ainda que informalmente, tem estad o fechada aos negrose mulatos brasileiros. Antropólogos "estrangeiros", como Peter Fry eLivio Sansone, com outros acadêmicos brasileiros, têm apoiado a pesquisa e a edição de livros sobre aspectos mais antropológicos da identidade e da identificação raciais no Brasil e, nesse processo, ajudaram a treinar alguns dos melhores jovens acadêmicos da Antropologia - entre eles, diversos afro-brasileiros. Temos tido desacordos amigáveis e não tão amigáveis ao longo dos anos a respeito de nossas perspectivas concorrentes sobre relações raciais no Brasil, como pode atestar qualquer pessoa que realmente tenha lido nosso trabalho. Assim, poderia a Fundação Ford ser acusada deajudar a patrocinar debateacadêmico saudável, mas doxa?Acho que não.

D ando outro exemplo, maisvoltado para políticas, o C entro de Articulação de Populações M arginalizadas, na Lapa, Rio de Janeiro, conhecido pela abreviatura, em português, CEAP, recebeu patrocínio de fundações sediadas nos EU A ena Europa com o fim de prosseguir a luta pela educação do público brasileiro edefender os direitos das crianças de rua, além de coordenar campanhas educativas sobre a história dos negros no Brasil, entre diversas outras iniciativas. Assim, 0 apoio estrangeiro, não apenas 0 apoio proveniente de fundações e instituições com base nos EU A, na verdade ajudou diversas organizações e instituições não-governamentais brasileiras a aumentar o nível do debate sobre desigual dade racial nas trinchei ras das políticas públicas, aumentar o número de acadêmicos brasileiros negros e mulatos, bem como expandir e aprofundar a agenda de pesquisa sobre tópicos relacionados com raça no Brasil.

$N$ enhum dos indivíduos e organizações mencionados poderia ser acuradamente caracterizado como simples imitador de paradigmas raciais originários dosEU A. N o caso do CEAP, seu diretor e fundador, I vanir dos Santos, foi órfão que viveu na rua e em diversos orfanatos durante a ditadura. Ao sair de um dos abrigos mantidos pelo estado - a Funabem, Santos decidiu reunir exinternos de asilos governamentais, como ele próprio, numa orga- 
nização (Santos, 1998) dedicada aos setores marginalizados da sociedade brasileira, entreeles os afro-brasileiros. N ão se podeconsiderar isto cópia do N AACP - o programa G reat Society, da política de reforma do bem-estar deBill Clinton, mas resultado positivo da confluência de iniciativas políticas afro-brasileiras, dos espaços entre o Estado brasileiro e a sociedade civil e a gl obalização (sim, globalização) de concessões e competição de patrocínio de fundações internacionais. A categoria de nação fica, mais uma vez, sem delimitação. 0 spontos de convergência políticana sociedadecivil são forjados por tópico (falta delar, crianças de rua, discriminação social etc.), em vez de por nacionalidade ou prerrogativa do Estado. As formas locais e internacionais de engajamento político têm interseção ese congel am dentro da categoria nação. I sso sugere, ao contrário da tese de Bourdieu eW acquant, que o local pode ser estimulado, não necessariamente violentado, através do engajamento com formas extra ou transnacional de pensamento político eengajamento com instituições e pessoas cujos compromissos materiais e políticos as colocam em conflito com as práticas ou políticas dos estados de sua origem territorial. T al visão do local não devese confundir com provincianismo.

$\mathrm{H}$ ardt e $\mathrm{N}$ egri captam, de maneira sucinta, os problemas conceituais e epistemológicos inerentes às justaposições de global elocal, que, nestainstância, situam os Estados U nidoscomo poder monolítico, eo Brasil, vítimalocal deten dências do tipo rolo compressor, totalizantes, corporativistas (se não imperialistas):

[... ] o problema se situa em uma falsa dicotomia entre o global e o local, pressupondo que o global acarreta homogeneização eidentidade indiferenciada, enquanto o local preserva heterogeneidade e diferença. Freqüentemente, implícita nesses argumentosestá a hipótese de que as diferenças do local são, de certa forma, naturais, ou pelo menos, sua origem permanece fora de questão. [...] Essa visão pode facilmente desembocar em uma espécie de primordialismo, que fixa e romantiza as relações e identidadessociais. 0 que precisa ser examinado, em vez disso, éprecisamentea produção da local idade, ou seja, as máquinas sociais que criam e recriam asidentidades ediferençasque são compreendidas como o local. (H ardt \& N egri, 2001:45)

A produção do local, neste caso, está nas relações de raça no Brasil, em justaposição não só com os Estados U nidos, mas uma história de ideologias antiafricanas, antinegro, indo do aparentemente benigno (o igualitarismo racial de Freyre, a raça cósmica de Vasconcelos) até o mais sinistro (fascismo, nazismo, neonazismo e outras formas desupremacia branca). M uitos conservadores da ex- 
cepcionalidade brasileira concentram-se na primeira justaposição - osEU A - enão na segunda. Como conseqüência, eliminam não só os paralelos entre políticas raciais nos EU A e no Brasil, mas entre outros Estados-nações nos quais a raça de fato importa.

3. Um D ebate Revisitado - O M ovimento $\mathrm{N}$ egro Brasileiro e a C orrupção Estrangeira

A história das acusações de influência deletéria afro-norteamericana dosEU A eoutrasformas deinfluência estrangeira, reais ou imaginadas, sobre o movimento negro brasileiro vai muito mais longe e fundo que o presente debate. Para os leitores que não têm familiaridade com a história e a literatura do $\mathrm{M}$ ovimento $\mathrm{Ne}$ gro brasileiro, apresento um fragmento traduzido de uma entrevista com o falecido J osé Correia L eite, honrado membro fundador da Frente $\mathrm{N}$ egra Brasileira, o primeiro partido político negro no Brasil, formado em São Paulo, em 1931. Em E di sse o velho militanteJ oséC orreia Leite(LeiteeC uti, 1992), elerecorda como notícias e informação a respeito de transnacionalismo negro fora do Brasil entraram pela primeira vez no discurso político afro-brasileiro. D e acordo com Leite, um baiano de nome M ário de Vasconcel os introduziu diversos textos de afro-norte-americanos dos EUA no M ovimento N egro de São Paulo e da Bahia. Vasconcelos traduziu trechos de TheBlack W orld e outros textos transnacionais negros para uma seção do jornal Clarim intitulada 0 mundo negro, tradução portuguesa do título da publicação daU N IA. M as, como observa Leite "[...] isso se deu em condições controversas".

A maioria dos negros brasileiros não aceitou as idéias apresentadas por G arvey, achando que Leite "queria fazer um movimento queera importado, um movimento deoutrosinteresses que não eram os nossos. Eles disseram um monte de coisas. Q ue eu estava criando uma questão racial. Propondo um modelo racista de outro lugar" (idem). Jornais como o Clarim d'Alvorada, órgão da F rente N egra Brasileira, refletiram o caráter transnacional do ativismo negro brasileiro desde os anos 1920. Ao introduzir as idéias de $M$ arcus $G$ arvey no contexto, através das páginas do Clarim d'Alvorada, Leite observa que $G$ arvey foi recebido com grande reserva nos Estados U nidos, apesar de ter encontrado apoio para fazer um grande trabalho. M as foi combatido por muitos negros norte-americanos, que o consideravam "um aventureiro". ${ }^{1}$ As recordações de L eite são interessantes por diversas razões pertinentes 
a este debate. Em primeiro lugar, os paralelos que traça entre si e Garvey, enquanto visionários, tentando mover-separaalém doslimites da subordinação racial que os confinava, no Brasil e nos Estados U nidos respectivamente, de modo implícito informam 0 que se torna mais explícito adiante, no texto: que a Frente $N$ egra Brasileira, como a U N IA de G arvey, era considerada um gesto temerário, com pouco apoio popular. Além disso, sua relevância para as idéias de $\mathrm{G}$ arvey de emancipação racial era considerada comparativamente. Assim, ao contrário de Bourdieu, W acquant e diversos brasilianistas, Leite tinha consciência do al cance dos debates a respeito do garveyismo nas duas sociedades. Sua disposição de apresentar as idéias de Garvey ao discurso público negro no B rasil sugere uma profunda consciência da importância da circulação de idéias dentro das redes políticas transnacionais negras, mesmo idéias impopulares - isso, em uma nação onde a noção de afro-brasileiro enquanto entidade política e cultural separada do Estado-nação brasileiro, já avan çando nos anos 1980, era considerada um ato de heresia.

Em terceiro lugar, o comentário de Leite sugere, entre muitos outros vislumbres, nesta breve passagem, que o importanteem G arvey não era sua origem nacional ou local de residência, mas seu compromisso com a luta pela igualdade racial para os povos de ascendência africana, a qual não se restringia à demarcação territorial nacional. Leite foi capaz de ver o garveyismo, entre muitos outros produtos artísticos, estéticos e políticos da diáspora africana, como implemento de luta e reflexão. Leite procurou e encontrou-se com muitos artistas, intelectuais e figuras do mundo negro. N icholas G uillen, o poeta afro-cubano, passou uma temporada em São Paulo com Leite e outros membros da F rente. 0 nacionalismo brasileiro, como a maior partedos nacionalismos, é, entre outras coisas, uma ideologia de inclusão, eé por isso que, como 0 próprio Leite comentou, ele e outros eram acusados de importar idéias estrangeiras, deimportar racismo, enquanto, junto com outros ativistas negros brasileiros, estavam tentando demonstrar ao seu Estado-nação que o racismo já tinha existido no Brasil. Q ue o seu patriotismo elealdade à nação fossem postos em questão, com acusações de bolchevismo levantadas contra eles, é consistente com a reação nacionalista brasileira à articulação de uma visão transnacionalista negra brasileira.

Através do século XX, as gerações subseqüentes de ativistas brasileiros negros (que é como muitos deles se referem a si mesmos) continuaram o diálogo transnacional da política negra. N os 
anos 1970, por exemplo, membros do M ovimento N egro do Rio deJ aneiro eSão Paulo deram início à campanha "Sou negro", com o objetivo de tornar visível a presença invisível, reprimida, de ne gros e mulatos brasileiros na vida pública e argumentar em prol da conscientização de uma identidade afro-brasileira distinta e de uma política baseada na história da escravidão racial, nas práticas religiosas e culturais de origem africana e em uma conexão com povos de descen dência africana em outras partes do mundo. T ambém convocavam brasileiros que não se consideravam negros ou mulatos, eaté brancos, a fazerem o mesmo. Ativistas negros como $\mathrm{V}$ anderlei J osé $\mathrm{M}$ aria, $\mathrm{H}$ amilton $\mathrm{C}$ ardoso eD eborah Santos dedicaram-se ao debate, à literatura e retórica transnacionais negras (H anchard,1994). Como na sutil descrição de M anthia D iawara das próprias experiências - criado na G uiné, incorporou o modo desevestir, a música eoutrosíconesculturais deidentidadee resistência negras da experiência afro-norte-americana dos EU A (D iawara, 1998) - osafro-brasilei rosinscreveram-seno discurso público negro transnacional de raça, nação, identidade e solidariedade, fundindo esses símbolos e práticas políticas e culturais às próprias experiências. M as, como D iawara e seus contemporâneos afrobrasileiros usaram afro nesse período, acredito que W acquant e Bourdieu também os considerariam imperialistas.

Finalmente, os argumentos levantados contra Leite eaFrente $\mathrm{N}$ egra Brasileira parecem-se com a crítica que Bourdieu eW acquant fazem a acadêmicos afro-norte-americanos dos Estados U nidos, como eu. São argumentos invariavelmentenacionalistase estatistas, assemelhando-se ainda ao modelo colonial francês do imperial ismo cultural. D iferentemente do inglês ou holandês, por exemplo, o modelo colonial francêsimpôs aos súditos das colônias a noção de que estas eram parteintegral da nação francesa, não somente na forma de um Commonweal th, como no caso dos ingleses, mas em termos normativos e pseudo-espaciais, enquanto departamentos da própria nação França. É mais que coincidência, portanto, que durante o período dos movimentos nacionalistas pan-africanistas na África colonial, um dos principais argumentos dos imperialistas franceses fosse 0 de que as colônias africanas francesas eram tão fundamentalmente diferentes das colônias britânicas, holandesas, bel gas e portuguesas, que a idéia da "unidade pan-africana" não só era impossível einaplicável, como redundante: os africanos franceses já tinham uma nação. 0 que eu sugiro aqui équeassim como a idéia imperial de nação francesa competia com nacionalismos africanos e pan-africanismos, também as 
Política T ransnacional N egra, Antiimperialismo eEtnocentrismo...

idéias brasileiras negras de identidade racial e diáspora entram em conflito com o imaginário nacional ista do freyreanismo eneofreyreanismo, bem como o imaginário colonial e neocolonial do luso-tropicalismo. N ão seria possível que o desprezo de Bourdieu e W acquant pela colaboração transnacional entre membros de um grupo marginal izado em termos raciais contivesse uma espécie de resíduo cultural (colonialismo francês) queel es próprios não identificam?

4. O rfeu e o Poder, T ransnacionalismo $\mathrm{N}$ egro e a "Q uestão Cultural"

U ma vez que 0 rfeu eo Poder utilizou uma metodologia concebida inicial mente por um italiano e o tema da minha pesquisa eram os norte-americanos de tipo diferente daquel es nos Estados U nidos, como, exatamente, consegui tornar-meo imperialista que me pintaram?

Para quem não conhece, 0 argumento formulado em 0 rfeu e o Poder éo seguinte: a hegemonia racial brasileira, da qual aideologia da democracia racial éuma parte, éum processo político e cultural que: a) enfatiza as contribuições afro-brasi lei rasà cultura nacional brasileira como traços naturais da identidade afro-brasileira; b) produz emantém condições de desigualdade; ec) nega as perspectivas de identidade e política afro-brasileiras como fenômeno distinto da política nacional. Esteúltimo ponto éconsistente com um modelo latino de pluralidade e diversidade dentro de um modelo que enfatiza homogeneidade nacional, característica de ambos os modelos coloniais - português e francês - e, em menor grau, do espanhol, completando os pontos em comum franco-ibéricos com respeito à lei colonial.

Concluo que, em resposta a tais condições, ativistas e organizações afro-brasileiros no Rio deJ aneiro e em São Paulo utilizaram práticas culturais para: a) promover e estimular a idéia de identidade e consciência afro-brasileiras, distinta das mitologias do Estado nacional de democracia racial e identidade nacional; e b) mobilizar brasileiros negros e mulatos contra práticas correntes de discriminação racial. 0 que me colocou em tantos problemas junto a diversos brasilianistas foi minha sugestão de que: a) o movimento negro, ou movimento dos pretos, reproduziu parte da preocupação com a identidade cultural encontrada em nível naci- 
onal; eb) freqüentemente enfatizou culturalismo, acima de política cultural.

Alguns interlocutores, e agora Bourdieu e W acquant, afirmam que, ao sugerir maior polarização na política racial brasileira e a necessidade de afastar o movimento da política culturalista, não só eu estava "norte-americanizando" as relações sociais no Brasil, mas de al guma maneira privando o ativismo afro-brasileiro de uma de suas principais diretrizes organizadoras eum de seus principais dispositivos políticos- a cultura, enfatizando aspectos ligadosabens, serviçoserecursos da articulação política, em vez dedesempenho ereconhecimento cultural. I sto, diversos comentaristas atribuíram à minha "norte-americanidade", em vez de a uma problemática mais geral, envolvendo grupos sujeitos a discriminação racial e questões de poder político. Laura Segato me identifica como "afro-norte-americano" em um artigo de 1996,

[... ]apontando para a especificidade da experiência do contingente africano (sic) nosEU A ea porção comum dehistória que compartilham com os brancosneste país. O u seja, a história deum tipo peculiar de capitalismo, de sacral ização do mercado, da conseqüente crença na guerra e nos meiosviolentos, deendosso de uma máquina estatal agressiva em rel ação ao exterior, de um caráter nacional de um modo geral beligerante, antipacifista [...]. (Segato, 1996:2-3)

Todos devem conhecer este tipo de crítica, baseada na caricatura dos Estados U nidos e seus povos, e na "porção comum de história", compartilhada por brancos e negros.

Já Peter Fry foi mais ponderado ao falar, de modo em parte autobiográfico, do meu trabalho, contando um incidenteno Rio, quando viajava com um amigo negro, em que ele, um branco "naturalizado" brasileiro, testemunhou um caso constrangedor motivado por questão racial, nas mãos da polícia. D epois do incidente, entrou em um

[...] bar cheio de gente de todo o tipo possível de 'aparência': jovens, veIhos, mulheres, homens, de todas as cores possíveis. 0 ambiente animado, de convívio, constituía um antídoto perfeito para o constrangimento policial. (Fry, 1995-1996)

Fry conclui 0 artigo sugerindo que sua experiência também constituía antídoto perfeito para minha análiseda "política racial brasileira" (expressão que emprego em meu trabalho), provando que eu estava "importando" categorias estrangeiras para a discus- 
são da sociedade brasileira, uma vez que não existe tal coisa - política racial - no Brasil.

Levando-se em conta os diversos países, dos assim chamados ciganos aos palestinos e judeus, que nacionalidades ou minorias étnicas negociaram e garantiram direitos civis e humanos somente, ou em grande parte, através da prática e distinção cultural? $\mathrm{N} \mathrm{e}$ nhuma. A expressão da diferença cultural, religiosa, sequer garante o caminho necessário rumo à igual dade política e socioeconômica. $\mathrm{N}$ a verdade, historicamente, a diferença cultural marcou grupos no sentido da marginal ização e exploração, ou da oposição erotização/repulsa, mas nunca os marcou como iguais aos opressores. Assim, parte do meu argumento em 0 rfeu e o Poder é que 0 M ovimento N egro do Brasil precisou de um sentido mais comparativo do relacionamento en tre política e cultura como problemática dos grupos raciais e étnicos marginal izados viven do em sociedades multiétnicas e multirraciais. 0 Brasil talvez seja caso anômalo, mas há anos, desde a publicação de 0 rfeu eo Poder, a explosão deorganizações, pesquisa einiciativas de políticas públicas criadas por mulheres e homens afro-brasileiros ao longo do eixo dos bens, serviços e direitos, sugere que os movimentos sociais afro-brasileiros, bem como os atores políticos nos partidos polítiCOS, que por muito tempo defenderam a população negra e mulata brasileira (assim como outras populações historicamentemarginalizadas), ampliaram seu território político. 0 s críticos podem afirmar que isso demonstra queo $\mathrm{M}$ ovimento $\mathrm{N}$ egro não tevetendênciaculturalista, massimplesmentese engajou nas práticas políticas permitidas durante o longo período da ditadura. J ustamente isso, porém, fazia parte do meu argumento. 0 único caminho para o movimento negro desafiar, de maneira mais direta, a desigual dade racial ea discriminação no B rasil, era fazer política aparentemente contrária à sua existência e formação: a política dos poderosos. As limitações das políticas de identidade afro-brasileiras são emblemáticas das limitações das políticas de identidade de um modo mais geral, independentemente da raça ou cor dos que a elas aderem; a preservação, o resgate e a reforma cultural, por si mesmos, podem ajudar a transformar uma determinada população, mas não transformam necessariamente uma política ou sociedade, nem libertam essa sociedade de seus costumes racistas.

Vamos considerar as tensões entre política e cultura no movimento negro no Brasil a partir de outro ponto de vista, em relação ao transnacional ismo negro: as formações literárias da Renaissance do $\mathrm{H}$ arlem e do movimento da $\mathrm{N}$ egritude $\mathrm{F}$ rancófona, dois 
dos movimentos mais famosos gerados entre as populações da diáspora negra. A gênese de ambos foi uma combinação de expressão artística e repressão política. A princípio, o uso de métodos surrealistas na poesia da N egritude foi, em parte, de acordo com Aimé C esaire, uma maneira de "esmagar os padrões 'normais' da linguagem, na tentativa de criar uma forma nova". N a introdução de Retorno à minha T erra $\mathrm{N}$ atal, de C esaire, $\mathrm{M}$ azisi K unene escreve que C esaireachava que "quebrando os padrões cuja ordem lógica tinha afirmado o racismo, ele tinha dado ao surrealismo um propósito" (1969:24), uma resposta estética à brutal repressão da França e da Bélgica aos movimentos anticoloniais africanos.

A R enaissance do $\mathrm{H}$ arlem surgi u após um período de repressão sel vagem de populações negras através dos Estados U nidos no período posterior à Primeira G rande Guerra, quando muitos soldados afro-norte-americanos retornaram do front europeu e encontraram a mesma discriminação que tinham deixado para trás, revoltando-se contra a posi ção contraditória do Estado dos EU A de exortá-los a lutar pela liberdade de outras pessoas e não pela própria. $\mathrm{N}$ as palavras de Alain Locke, seu líder, a Renaissance do $\mathrm{H}$ arlem recebeu apoio de uma coda do $\mathrm{N}$ ovo $\mathrm{N}$ egro, que buscava paridade para o negro através da expressão artística. Ao mesmo tempo em que falava da importância do transnacionalismo negro (o que chamava de "consciência deraça") e deum incipienteterceiromundismo entre povos não brancos, em plano global, Locke deixava entrever dúvidas a respeito das perspectivas de tais caminhos para a remoção das restrições nacional-territoriais sobre os afro-norte-americanos nos Estados U nidos. R eferindo-se a garveyismo e consciência de raça global, escreve:

[... ] a participação construtiva nessas causas não pode deixar de dar ao negro valioso incentivo degrupo [...] mas no presente, a esperança mais imediata repousa na reavaliação por brancos e negros, igualmente, do negro, em termos de seus dotes artísticos e contribuições culturais, do passado e para o futuro. (Locke, 1925: 15)

M ais adiante, L ocke especula sobre ganhos políticos e sociais possíveis através da expressão cultural negra:

[...] especialmente o reconhecimento obtido no nível cultural deveria, por sua vez, provar-se chave para a reavaliação do negro, a preceder ou acompanhar qualquer subseqüente melhoria considerável das relações raciais. (ibidem)

A atuação pessoal e política de Locke excluía as possibilidades de ação política e confronto diretos. Ele pode ter sido um homem da 
raça, mas, ao contrário de G arvey, não era um homem da massa. $\mathrm{N}$ o entanto, considerou a produção cultural como caminho da autodeterminação, em um momento particular nahistória dosEU A, quando outros atalhos para a autodeterminação de afro-norte-americanos dos EU A estavam ou fechados ou impedidos. Em última instância, Locke viu a produção cultural como complemento do protesto político formal eda mobilização social.

Seria possível tensões semelhantes informarem a história do M ovimento N egro no Brasil? Poderia ser que o lento desenvolvimento da sociedade civil, junto com a negação da existência de racismo na sociedade brasileira, tanto entre a esquerda quanto entre a direita, fossem os equival entes brasilei ros dos caminhos bloqueados rumo à articulaçã̃o política, destramente anal isados por historiadores como K im Butler (1998) - o que tornou a política culturalista mais plausível e, aparentemente, mais viável que outras formas de política? Analisando-se populações marginalizadas do mundo moderno, independentemente de cor ou nacionalidade, não seria possível que em muitas delas a expressão autoconsciente de diferença cultural tenha se moldado, em parte, em função do grau de subordinação a um grupo dominante (numérica, política ou economicamente)? $\mathrm{N}$ a ausência de poderio militar e recursos naturais (a saber, minerais, petróleo, pedras preciosas), a cultura não poderia se tornar o instrumento escolhido pelas populações marginalizadas por formar a última barreira - além dos próprios corpos- entre elas eosqueas dominaram econtinuam afazêllo - 0 último recesso, o final, do terreno político, no qual o dominado não é inteiramente vencido?

Com exceção da moderna diáspora judia, para a qual o fato histórico e as imagens simbólicas do $\mathrm{H}$ olocausto moderno tornaram inevitável a (re)presentação da violência, as descrições populares da maioria das populaçỗes da diáspora na história moderna fixaram-se de maneira obsessiva - ou pelo menos concentrada em noções deidentidadeecultura, em vez de, digamos, sua relação com o sistema de Estados-nações, modo de produção ou violência e coerção distribuídas por um estado ou população nacional-territorial. Assim, a resistência é muitas vezes colocada em termos de práticas culturais - as "armas dos fracos" (Scott, 1985) - como se fossem o único modo de se relacionar com grupos sociais dominantes. Essa reação à opressão, porém, como argumentei, contém no seu bojo ambas, a perspectiva de resistência, assim como a lógica da dominação. 0 "como" as pessoas resistem, as "armas" escoIhidas, dizem tanto sobre a natureza e as condições da luta social e 
política como os próprios atos específicos de resistência. Estudose práticas de grupos subalternos freqüentementecontêm preconceito em relação a modos mais informais, menos diretos de protesto político, como o caso dos afro-brasileiros atéo crepúsculo da ditadura. Enfocar tópicos como "política cultural" e "cultura de resistência" em diversas disciplinase camposé, em parte, conseqüência desta virada.

U ma das conclusões da minha pesquisa foi: o confronto direto com o Estado brasileiro e a sociedade civil quanto a questões de desigualdade racial requereria, dos brasilei ros negros e mulatos que procuravam rever as desigualdades, organização política enquanto grupo, para confrontar a quimera da igual dade racial mantida pelas elites brasilei ras e rejeitar as distinções categóricas entre negro emulato. Parte da razão dessa concl usão está na pesquisa demográfica conduzida por acadêmicos brasi lei rosreferentesà muito citada ideologia da democracia racial, em que aqueles classificados como pardos ou mulatos de algum modo se encontravam em meIhor situação, em termos materiais, que os brancos ou negros no B rasil. A segunda justificativa para a minha conclusão foi numérica, nada tinha a ver com fenótipo, raça ou cor. Simplesmente faz sentido no caso de atores políticos em busca de maior poder político e econômico para tentar ampliar sua clientela política e cultural.

Conforme observa J ohn French em sua bem elaborada crítica da obra deBourdieu eW acquant (French, 2000), a teseda "saída mulata" inicialmente colocada por Carl D egler há mais de trinta anos (D egler, 1971) ainda se mantém como proposta teórica. C omo T homas Skidmore observou há muito, a tesenunca foi provada ehá dados demográficosque sugerem outras coisas. A pesquisa demográfica de Paes de Barros (s/d), Peggy Lovell (1991) e Edward Telles (1988) sobre distinções socioeconômicas entre pretos epardos sugere que, enquanto existem diferenças significativas entre pretos e pardos nos indicadores de qual idade de vida, os pardostendem a ser maiscomo os negrosque como os brancosem termos de renda. Por contraste, o sociólogo N elson do Valle Silva, analisando dados do recenseamento de 1960 e 1976 (que utilizaram categorias preto e pardo) conclui que "negros e mulatos são igualmente discriminados. Isto claramente contradiz a idéia de uma saída mulata como essência das relações de raça brasileiras" (Silva, 1985:54-55). U m trabalho mais recente em colaboração com C arlos $\mathrm{H}$ asenbalg e dados do recenseamento de 1987 reafirma conclusões anteriores (Silva eH asenbalg, 1999). A força ea re- 
percussão da tese da "saída mulata" de D egler éinerenteà sua aceitação social e cultural, tanto no plano nacional como no transnacional, apesar da ausência de qual quer possi bilidade deverificação empírica, ou seja, da falta de "dados" que, de alguma maneira, comprovem que os mulatos no Brasil, independentementedeclasse, educação e posição socioeconômica, vivessem vidas mais agradáveis. C omo sugeri em 0 rfeu eo Poder, a tese da saída mulata ébasicamente uma formação ideológica de elite; sua força reside na sua articulação hegemônica como sen so comum, não em sua materialidade. Em última análise, o debate contemporâneo sugere que essa tese, intensamente debatida dentro do Brasil, não se configura como o ponto pacífico freqüente e grosseiramente apresentado para consumo externo.

Encontra-se, porém, na raiz dessa formulação de senso comum, uma hipótese básica sobrea rel ação entre "mistura de raça" e engenharia social, a que $\mathrm{N}$ ancy Stepan se referiu como miscigenação positiva (Stepan, 1991). U ma questão que os autores não colocam e que, comparando-se, une ambos, o caso brasileiro e o dos EU A, éseexi ste correl ação en tre classificação de cor eigualitarismo racial, ou seja, a multiplicidade de categorias fenotípicas conota maior ou menor igualdade racial? $0 \mathrm{u}$, em linguagem mais corrente: mestiçagem, crioulização, hibridez e mulatização são indicadores de maior diversidade e tolerância racial? 0 nde as tendências dos estudos culturais luso-tropical istas neofreyreanos brasileiros, deBourdieu eW acquant epós-estruturalistas secruzam éna prontidão para considerar a classificação racial "maisfluída" como uma forma de jogo profundo, um jogo de coquinhos de Bahktin de "monty detrês cartas", em queas relações de poder são radicalmente afetadas meramente mudando-se os modos de classificação humana deacordo com a cor ou o fenótipo. Ah, sea mudançana posição do sujeito fosse tão simples...

$\mathrm{N}$ um artigo do $\mathrm{N}$ ew York Times sobre o filme brasileiro "O rfeu N egro", C aetano Veloso coloca que minhas conclusões em relação ao uso que faz o M ovimento N egro brasileiro do preto tanto para negros como para mulatos brasileirossimplificavam a realidade brasileira, podendo levar à "intolerância racial" (Veloso, 2000). As premissas do argumento deVeloso compõem um paralelo com as de Bourdieu eW acquant: o Brasil éum local de miscigenação; osEU A, com a hipodescendência como característica de codificação racial, não é. Além disso, a hibridez exemplifica jogo e fluidez, não desigualdade. Vamos considerar a premissa de Vel oso em si mesma, em perspectiva comparativa, sem nos referirmos nem aos Estados U ni- 
dos e nem ao Brasil. Se se fosse aplicar a premissa do sr. V eloso miscigenação raçial igual a democracia racial - para encarar as relações de raça na África do Sul ou no H aiti, por que a miscigenação não levou, aí, nesses doislocais, ao igualitarismo racial? Estendendo a correlação aos lugares de influência ibérica no N ovo M undo, como explicaríamosa coexistência depreconceito antinegro com celebração nacional da miscigenação em pontos tão distintos quanto V enezuela, Equador eC uba? Voltando aosE stadosU nidos, as categorias mulato, oitavão e quadroon (filho de branco com mulata) eram classificações operativas de "cor" e "raça" na simbologia e sociologia do apartheid social e da segregação, mas duvido um comentarista sério da história dos EU A sugerir quea presença de oitavão e quadroons levasse à igualdade racial.

Veloso - e outros, que tiraram conclusões semel hantes - negligenciam as implicações das próprias afirmações sobre racismo na sociedade brasileira. 0 racismo contra os afro-brasileiros, queo próprio Veloso muitas vezes reportou em sua música eem entrevistas, já existeno Brasil. Assim, sea celebrada hibridez racial coexiste com intolerância racial, o queisso nos diz sobrea plausibilidadeda sugestão de que ou a hibridez racial ea intolerância racial são antitéticas uma em rel ação à outra ou a hibridez racial leva à tolerância racial?

Ao considerar o Brasil do ponto de vista da política racial comparativa, acredito queambos oscenários são al tamenteimprováveis, na verdade, inexistentes, nas políticas multiraciais, nas quais descen dentes de escravos africanos habitam o mesmo espaço que descendentes de grupos indígenas e descendentes de europeus. A discriminação racial contra os negros tem coexistido com model os multipolares, bem como bipolares de classificação racial. 0 erro analítico cometido por Bourdieu e W acquant, bem como al guns defensores baseados nos EU A da miscigenação e hibridez como melhoria de condições raciais, é a equação de classificação racial ou fenotípica - queé uma faceta putativa da dinâmica racial - com a totalidade das interações dos grupos citados. Essa equação é uma forma de hipóstase, e base insuficiente para acessar a totalidade da experiência das relações raciais no Brasil ou qualquer outro lugar.

0 desafio específico para muitos acadêmicos brasileiros/brasilianistas, ao considerar osmovimentos sociais negrosbrasileiros como faceta da política negra transnacional, está em ver a participação de organizações tais como a Frente N egra Brasileira não só como forma de apresentação dehistória nacional eregional, 
mas também como faceta integral de uma comunidade multinacional, multilingüe, ideológica e culturalmente plural - uma comunidade imaginada, sequiserem, mas não necessariamentelimitada por um paísterritorial singular. A segunda conceituação exige que vejamosno transnacionalismo negro, não um aspecto disparatado, isolado, ou das históriasnacionais ou da história das relações internacionais, mas como traço contínuo, recorrente, da política dos séculos XIX, XX e, agora, XXI, em que tópicos como livre associação, reconhecimento cultural e religioso, autonomia territorial e acesso igual a bens, serviços e recursos manifestam-se, completamente ou em parte, como foi o caso em movimentos sociais na África do Sul, Jamaica, Brasil, Colômbia, R eino U nido e muitos outros Estados-nações. O s el os transnacionais entre atores políticos africanos, caribenhos e norte-americanos mostram grande semel hança com outros el os transnacionais, não governamentais, da primeira metade do século XX - anarco-sindicalismo, comunismo, sindicalismo e outros movimentos globais seculares.

A política negra transnacional, ou o que caracterizei em outro ponto como afro-modernidade ( $\mathrm{H}$ anchard, 2000) ajuda a sublinhar aquilo a queJ orge C astañeda se refere como "nacionalismo longitudinal" (1994:308): o desenvolvimento de relações horizontais, sem base estatal, entre atores políticos em vários Estados-nações, com o propósito de desafiar ou derrubar políticas em um ou mais Estados-nações. As filiações cruzadas através e acima de fronteiras territoriais problematizam qualquer caracterização de rel ações internacionai s e inter-Estados como interação de entidades soberanas, politicamente discretas em termos de território. C onceituada desta maneira, a questão da nacionalidade ou da origem pode ser efetivamente traduzida no contexto analítico mais amplo da interface de uma população-sujeito particular, de um lado (sul-africanos negros, por exemplo), com um regime (aparthei d) demai oria racial politicamente dominante(africâners). D essa maneira, os métodosutilizados para responder a condições particulares de desigualdade são, ao mesmo tempo, codificados de maneira universal e cultural, na medida em que fenômenos tais como marchas, greves, rebeliões, freqüentemente operam lado a lado com formas de religião, dança, expressão corporal eatos cotidianos de resistência, com o fim de articular a natureza específica local de sofrimento e protesto.

Em muitos países, os transnacionalistas negros têm operado nos interstícios das rel ações internacionais inter-Estados por bem mais que um século e freqüentemente fundido política antiimpe- 
rialista com política anti-racista. Em muitas sociedades plurais, onde descendentes de africanos autoconscientes se viram em posição relativamente impotente em rel ação a outro grupo étnico, são diversas as histórias de tentativas (al gumas bem-sucedidas) de criação de coalizões que ultrapassam linhas raciais, étnicas efenotípicas: de negros e mulatos no H aiti, durante a R evolução H aitiana; deafro-trinidadianoseíndios do lestede T rinidad; demodo semeIhante, na G uiana e de negros e mulatos na J amaica. Sugiro esses exemplos do N ovo M undo porque não só atravessam fronteiras nacionais, mas também, ao que se presume, fronteiras "culturais" e coloniais. M inha conclusão, em parte, baseou-se nessa história comparativa mais ampla. Aqui nos defrontamos com uma questão conceitual de raiz: a capacidade dos estudiosos de se deslocarem para além de categorias sociológicas e políticas já prontas, com 0 fim de apreender fenômenos identificados sob os rótulos movimento por direitos civis dosEU A etransnacionalismo negro eexaminar fenômenos políticos, sociais e culturais associados a locaise épocas específicos ao lado de fenômenos presumivelmente distintos por formas de demarcação lingüística, territorial ou outras. Esse desafio não cabe apenas aos acadêmicos que tratam da história, mas também aos teóricos da maneira como o estudo do transnacional ismo negro de várias manei ras desafia os caminhos conhecidos para se analisar movimentos nacionalistas ou de "questão única", permitindo-nos considerar certas formas de solidariedade e mobilização políticas através de fronteiras nacionais como agrupamentos e congregações não meramente coincidentes com o sistema do Estado-nação. Assim, enquanto Bourdieu e W acquant vêem o movimento por direitos civis dos EU A como filosofia da práxis unificada e até mesmo hegemônica, no interior do lexicon daluta social em todo o mundo, eu vejo o movimento por direitos civis dosEU A como agrupamento ou congregação dediversastendências ideológicas e políticas, com suas próprias valências internacionais e transnacionais.

\section{Comentários Finais}

0 ataque de Bourdieu e W acquant em alguns aspectos tem relação com o hábito queW acquant demonstra de descontextual izar a produção cultural negra e apresentar essa descontextualização como virtude ou força, conforme evidenciam al guns de seus escritos sobre boxe nos Estados U nidos. Essa ligação final é cruci- 
al, acredito eu, para o entendimento de como o uso indiscriminado das categorias sociológicas e a recusa em incorporar as peculiaridades específicas dastensões entre política e cultura no B rasil são sintomáticos de uma interpretação, de um modo geral equivocada, da atuação negra no trabal ho de W acquant.

A reputação emergente de Wacquant enquanto intelectual-boxeador deve-se principalmente a três anos de trabalho de campo participante-observador nazona sul deC hicago, treinando em vários ginásios de boxe, principalmente o Stoneland Boy's Club (Wacquant, 1998:329). Como praticante, o próprio Wacquant se aproxima do boxeatravés do que chama de sociologia carnal, uma sociologia do desejo corporal de distinguir sua consideração do esporte da maior parte da literatura jornalística sobre boxe. Ele caracteriza o boxe como ofício corporal, uma forma de capital do corpo que, segundo conclui, os afro-norte-americanos têm em abundância.

D eatletas em geral eatletas afro-norte-americanos em particular, Wacquant escreve que são performáticos e entretenidores, não líderes carismáticos, como são aquel es "que constituem as verdadeiras forças revolucionárias da história" (W acquant, 1996:6):

$0 \mathrm{~s}$ atletas não mobilizam o povo, nem oferecem uma nova visão de mundo, mas inscrevem a própria individualidade no mural da cultura pública, transformam as suas vidas e provêem modelos de autodomínio, para que os outros também tentem alcançar um bom desempenho. Não são de outro mundo, são deste mundo. "N ão são transgressores da tradi ção, mas expressões dela; não inovadores, mas ritual istas. I sto éparticularmente verdadei ro da cultura e da história africana-norte-americanas [...]". (ibidem:7, ênfases minhas).

A verdade afirmada aqui - que cultura e história afro-norte-americanas são fonte de ritual, mas não de inovação - é espantosa, por vários motivos. V islumbra-se ingenuidade antropológica no bojo da premissa de que a "tradição" de qual quer cultura possa ser vazia deinovação. Para os fins daminha resposta, porém, eu gostaria de enfocar apenas duas facetas dessa "verdade", que apontam a leitura duplamente equivocada da articulação cultural e política afro-norte-americana dosEU A. A distinção implícita em Wacquant entre política ecultura se manifesta na distinção entre carisma e persona: liderança carismática se al inha com a primeira; persona, com a última. N o entanto, como se pode manter tal distinção avaliando uma população cuja própria rel ação com a articulaçã̃o política e cultural nunca foi tão claramente dividida? 
O s atletas negros (homens e mulheres), sem falar nos pregadores, agentes funerários e outras ocupações profissionais, tinham muito mais status nas comunidades negras que sua contrapartida na sociedade enas instituições brancas dominantes, levando al guns comentaristas, como E. Franklin Frazier, a chegar ao ponto de concluir quea burguesia negra não era uma burguesia deverdade. $\mathrm{N}$ ão épreciso defender as conclusões de F razier para conhecer a disjunção sociológica entre posições de status nas comunidades branca e negra. A distinção sociológica genérica de W acquant entre carisma e persona e entre inovação e ritual, só seria acurada se existisse simetria de correlação de status entre brancos e negros.

M uitos atletas afro-norte-americanos dos EU A têm capital político e cultural que em muito ultrapassa o espaço das traves, da quadra de tênis, da quadra de basquete, campo de beisebol ou ringue deboxe- dePaul Robeson atéum negro conservador contemporâneo como J. C. Watts. A mudança do mundo dos esportes e suas implicações culturais e políticas para a arena dos negócios e partidos políticos, com suas próprias implicações, éuma transição que os atletas afro-norte-americanos dos EU A fazem com cada vez maisfreqüência. 0 esporterepresenta um dos poucos caminhos de sucesso para negrosna sociedade branca. 0 capital social ecultural acumulado numa esfera da sociedade, mesmo o capital corporal do atleta profissional, invariavel mente vem à tona e équestionado e utilizado em outras esferas. As vidas públicas - e, às vezes, particulares - deJ ack J ohnson, Althea G ibson eJ oe L ouis, entreoutros, ilustram como éproblemático o raciocínio deWacquant dedistinção persona/carisma para o atleta profissional afro-norte-americano nos EU A. N ão só o expõe a uma interpretação equivocada da importância simbólica e política dos atletas afro-norte-americanos dos EU A dentro do domínio do esporte, mas também fora dele, na política formal eem movimentos sociais, tais como "o movimento por direitos civis" a que se refere.

Se aceitássemos a distinção de W acquant, uma figura como M uhammed Ali não seria carismática; J oe L ouis, que representou a vitória dosEU A sobre o fascismo al emão através do sucesso edas vitórias arduamente conquistados, seria, de acordo com a tipologia deW acquant, destemundo enão de outro mundo. Sugar Ray Robinson, até hoje expoente em qualquer forma de arte marcial, capaz de nocautear um oponente andando para trás seria também exemplo de pessoa que não está entre os "transgressores da tradição, mas expressões dela; não inovadores, mas ritualistas". 
Alguns leitores poderiam achar que falar dos escritos de W acquant sobreboxee esporte em geral éuma digressão do debate sobre imperialismo cultural dosEU A no B rasil. M as, como sugeri, no início, as implicações de seu ataque se estendem para além das fronteiras do Brasil edos Estados U nidos. Também estão em questão temas como presunção, inten ção e método. N em nos EUA, nem no Brasil, a população de descendência africana opera fora dos papéis sociológicos dominantes, do senso comum, já prescritos para ela na academia e na sociedade. 0 que os define é unicamente a relação com a cultura nacional, a sociedade e o Estado e, por implicação, as instituições dominantes, costumes e val ores das respectivas sociedades. Como eu, o "norte-americano" ou a "pessoa de cor" só existem dentro de categorias analíticas individuais ("o atleta negro"). Em suma, são estáticos. N ão têm papéis múltiplos ou identidades multifacetadas, nem servem de produtores culturais ou atores políticos fora de uma "incumbência do papel social" dahrendorfiana. $0 \mathrm{~s}$ atletas homens africano-norte-americanos dos EUA e os atores políticos negros no Brasil são mais multifacetados, dinâmicos e, em última instância, "progressistas" do que permitiriam Wacquant e as sociologias de Wacquant e Bourdieu.

Como explicar essa lacuna entre a sociologia de Wacquant e a experiência vivida por afro-norte-americanos dos EU A e afrobrasileiros? Se o imperialismo cultural pode ser caracterizado como nivelamento ou atenuação da diferença através da racionalização de imperativos culturais e políticos alternativos, então as intervenções de Bourdieu e W acquant são, sem dúvida, cabíveis; como os casos reais de imperialismo cultural, suas perspectivas e descartes têm impacto sobremais de uma localidade e são transnacionais em escala, utilizando as categorias de nação, cultura e imperialismo para, em suas próprias pal avras, "universal izar particularismos ligados a uma tradição histórica singular, fazendo com que sejam reconhecidos como tais". No entanto, uma vez que eles não são nem capitalistas, nem representantes do Estado, talvez seja melhor caracterizar sua crítica como meramente imperiosa, não imperialista.

D e minha parte, concluo que as presunções de Bourdieu e W acquant em relação ao movimento por direitos civis dos EU A, 0 movimento negro no Brasil e a política cultural afro-norte-americana dos EU A formam uma ilha de etnocentrismo e incorrigibilidade cultural sem pontes nem barcos para atravessar a distância. As limitações de interpretação de "The Cunning of Cultural 
I mperialism" brotam da incapacidade de identificar e reconhecer formas de cultura e política não necessariamente coincidentes com política partidária, nacionalista (identidade) e sindicalista classista, formas de política das quais, na maior parte do século $X X$, as populações negras dos Estados U nidos, B rasil eaté mesmo França, ficaram, em larga medida, excluídas e atémesmo marginalizadas. Assim, com amigos como Bourdieu eW acquant, os atores e organizações políticos negros, as comunidades que os produziram, bem como aquel es que dedicam parte de suas vidas a estudar seus movimentos, não precisam de inimigos.

\section{N otas}

1. Segue o texto em português: "N osEstados U nidos, o G arvey foi recebido com muita reserva, apesar de ter encontrado apoio para fazer um grandetrabalho. M asfoi combatido por muitos negros norte-americanos, que 0 achavam um aventureiro [...] Como $\mathrm{M}$ arcus $\mathrm{G}$ arvey foi considerado um visionário, e eu acabei fican do um pouco visionário aqui, querendo fazer um movimento que era importado, um movimento deoutrosinteresses quenão eram propriamentenossos. D isseram uma porção decoisas, que eu estava criando um quisto (sic) racial, propondo um model o racista para cá. E ficou muito confuso por aí".

\section{Bibliografia}

BO U RDIEU, PierreeW ACQ U ANT, Loïc (1999). "T he C unning of C ultural I mperialism". Theory, Culture and Soci ety, vol. 16, no 1, pp. 41-58.

BUTLER, Kim D. (1998). Freedoms Given, Freedoms Won: Afro-Brazilians in Post-Abolition, São Paulo and Salvador. N ew Brunswick, N .J., Rutgers U niversity Press.

CAST AÑ ED A, J orge (1994). U topia U narmed: T he L atin American L eft After the Cold War. N ova York, Vintage Books.

CESAIRE, Aime (1969). Return to $M$ y $N$ ative Land. M iddlesex, Penguin.

D AH REN D O RF, Ralf (1959). Class and Class Conflict in Industrial Society. Stanford, Stanford U niversity Press.

D AW SO N , M ichael (2001). Black V isions: TheR oots of ContemporaryA frican-American Political I deologies. Chicago, U niversity of C hicago Press.

DEG LER , C arl N . (1971). N either Black N or W hite: Slavery and Race Relationsin Brazil and the $U$ nited States. N ova York, M acmillan.

D IAW ARA, M anthia (1998). In Search of A frica. C ambridge, M ass., H arvard U niversity Press.

FREN CH , J ohn D . (2000). "T he M issteps of Anti-Imperialist R eason: B ourdieu, W acquant and $\mathrm{H}$ anchard's 0 rpheusand Power". (Seção especial sobre o multiculturalismo e os intelectuais). Theory, Culture \& Society, vol. 17, nำ1, pp. 107-129.

\section{4}


PolíticaT ransnacional N egra, Antiimperialismo eEtnocentrismo...

FRY, Peter (1995-1996), “O queaC inderelaN egra tem a dizer sobrea 'política racial' no Brasil". Revista da U SP, no 28, dez-fev., pp. 122-135.

H AN CH ARD, M ichael (1990). "I dentity, M eaning and the African-American". Social Text, Ano 24, vol. 8, ํㅡ 2, pp. 31-42.

(1994). O rpheus and Power: The M ovimento N egro of Rio de Janeiro and São Paulo, Brazil, 1945-1988. Princeton: Princeton U niversity Press.

_ (1996). "Americanos, Brasileirosea C or daE spécie H umana: U ma Resposta a Peter Fry". Revista da U SP, no 31, set.-nov., pp. 164-175.

_ (ed.) (1999). Racial Politics in Contemporary Brazil. D urham, N .C., D uke U niversity Press.

H ARDT, M ichael e N EGRI, Antonio (2001). Empire. C ambridge, H arvard U niversity Press.

H O LLIN GER, D avid A. (2000). Postethnic America: Beyond M ulticulturalism. N ova York, Basic Books.

JAM ES, W inston (1998). H olding Aloft the Banner of Ethiopia. Londres, Verso.

KELLEY, Robin D. G. (1999). "Problem: Black H istory's G lobal V ision, 1883-1950". The Journal of American History, dezembro, pp.1045-1077.

LEIT E, J osé C orreia \& C uti (1992). E D isse o Velho M ilitanteJ oséC orreia L ei te. São PauIo, Secretaria M unicipal de Cultura.

LIN D , M ichael (1996). T heN ext American $N$ ation: TheN ew $N$ ati onalism and the F ourth American Revolution, N ova York, Free Press Paperbacks.

_ (1997). U p from Conservatism: W hy the Right isW rong for A merica. N ova York, Free Press.

LO CKE, Alain (1925). The N ew N egro. N ova York, A. e C. Boni.

LO VELL, Peggy (ed.) (1991). D esi gualdade Racial no Brasil C ontemporâneo. Belo H orizonte, Cedeplar/FACE/U FM G.

M I LIBAN D, Ralph (1983). "State Power and C lass Interests". N ew Left Review, nํㅜ 138, março-abril, pp. 57-68.

M O O RE, Richard (1992). "T he N ame 'N egro': I ts O rigin and Evil U se". In R. M oore, Caribbean $\mathrm{M}$ ilitant in $\mathrm{H}$ arlem. Londres e Bloomington, Pluto Press e Indiana U niversity Press.

N AISO N , M ark (1984). Communi stsin H arlem duringtheD epressi on. N ova York, Grove Press.

PATTERSO N , T iffany R. \& KELLEY, Robin D . G . (2000). “Unfinished M igrations: Reflectionson the African D iaspora and the M aking of the M odern W orld". African Studies Review, vol. 43, nำ1, abril, pp. 11-46.

_ (1999). "N otes on Racial and Political Inequality in Brazil". In M. G. H anchard (ed.), Racial Politics in Contemporary Brazil. D urham, N C, D uke U niversity Press, pp. 154-178.

RO BIN SO N , C edric (1983). Black M arxism: TheM aking of theBlack Radical Tradition. Londres, Zed.

SAN TOS, Ivanir dos (1998). Racial Politics in Contemporary Brazil. Durham, N C, Duke U niversity Press.

SC OT T, J ames C. (1985). W eapons of the Weak: Everyday Forms of Peasant Resistance. $\mathrm{N}$ ew $\mathrm{H}$ aven, Yale U niversity Press. 
M ichael $\mathrm{H}$ anchard

SKID M ORE, Thomas E. (1992-1993). "Race Relations in Brazil". Camoes Center Q uarterly, vol. 4, no 3-4, outono/inverno, pp. 49-57.

SE G AT O, Rita Laura (1996). "T he Colour-Blind Subject of M yth or W here to W atch Africa in Television". Série Antropologia, no 205, D epartamento de Antropologia, Universidade de Brasília, pp.1-24.

SH OH AT, Ella \& ST AM, Robert (2001). Black Renai ssance. N oir, primavera.

ST EPAN , N ancy (1991), The H our of Eugeni cs: Race, $G$ ender, and $N$ ation in Latin America. Ithaca, NY, C ornell U niversity Press.

ST EW ART, Charles (1999). "Syncretism and its Synonyms". Diacritics, vol. 29, no 3, outono, pp. 40-62.

TAYLOR, Charles (1985). "Understanding and Ethnocentricity". Philosophy and the H uman Sciences, vol. 2, pp. 116-134.

TELLES, Edward (1988). D emography.

SILVA, N elson do Valle (1985). "TheH igh C ost of N ot Being W hite in Brazil". In P.-M . Fontaine(ed.), Race, Classand Power in Brazil. LosAngeles, U C LA, C enter for African-American Studies, pp. 54-55.

— \& H ASEN BALG, C arlos (1999). "N otes on Racial and Political Inequality in Brazil". In M. H anchard (ed.), Racial Politics in Contemporary Brazil. D urham, NC, DukeU niversity Press, pp. 154-178.

_ \& H ASEN BALG , C arlos A. (1992). Relações Raciais no Brasil Contemporâneo. Rio de Janeiro, Rio Fundo Editora.

VELO SO, Caetano (2000). "O rpheus, Rising from C aricature". The N ew York Times, seção Artes e Lazer, 20/8.

VO N ESCH EN , Penny M . (1997), RaceA gainst Empire: Black Americansand Anticolonialism. Ithaca, Cornell U niversity Press, 1997.

W ACQ U AN T, Loïc (1998). "T he Prizefighter's Three Bodies". Ethnos, vol. 63, no 3, pp.325-352.

_ (1996). "From Charisma to Persona". The Charisma of Sport and Race. Berkeley, Townsend $\mathrm{C}$ enter for the $\mathrm{H}$ umanities, pp. 6-7. 